\title{
De achterkant van het openbaar bod
}

\author{
Over de opkomst, ontwikkeling en normering van de pre-wired back-end
}

\author{
Mr.J. Barneveld*
}

Pre-wired back-end structuren zijn in de overnamepraktijk ontwikkeld om na een openbaar bod tot $100 \%$ controle te komen. In dit artikel staan de opkomst en normering van die structuren centraal. Daarbij wordt bijzondere aandacht besteed aan de market practice om back-end-transacties aan additionele voorwaarden te onderwerpen.

\section{Inleiding}

Overnames van Nederlandse beursgenoteerde vennootschappen worden vrijwel altijd gestructureerd als een openbaar bod op de aandelen van de doelvennootschap. Aan die structuur is evenwel een belangrijk nadeel verbonden: iedere individuele aandeelhouder van de doelvennootschap zal zijn aandelen moeten aanbieden onder het bod, voordat de bieder zich honderd procent eigenaar kan noemen. Omdat de wettelijke uitkoopprocedure niet altijd een oplossing biedt voor dit probleem, zijn er in de praktijk verschillende structuren ontwikkeld die ertoe strekken de bieder een zeker pad naar volledig eigendom te bieden. Op grond van de bepalingen van Boek 2 Burgerlijk Wetboek (BW) behoeven deze back-end structuren goedkeuring van de algemene vergadering van de doelvennootschap. Die goedkeuring wordt steeds vaker reeds voorafgaande aan de gestanddoening van het bod gegeven. In mooi Nederlands is dan sprake van een pre-wired back-end structuur.

Niet alleen de pre-wired back-end structuren zelf zijn een product van de praktijk, dat geldt in belangrijke mate ook voor de voorwaarden waaraan die structuren doorgaans worden onderworpen. Omdat back-end structuren als zodanig niet wettelijk zijn geregeld en slechts beperkt door de rechter zijn getoetst, zoeken partijen daarbij houvast in de market practice, ofwel: dat wat eerder is gedaan. Recente transacties tonen evenwel aan dat back-end structuren nog volop in ontwikkeling zijn en dat de in de praktijk ontwikkelde voorwaarden niet in beton gegoten zijn.

In deze bijdrage staan de ontwikkeling en normering van prewired back-end structuren centraal. Om de back-end structuur in een breder perspectief te plaatsen, zal eerst worden besproken waarom het probleem dat men daarmee in Europa probeert op te lossen, in de Verenigde Staten nauwelijks

\footnotetext{
Mr. dr. J. Barneveld is advocaat bij De Brauw in Amsterdam en dit jaar werkzaam bij Wachtell, Lipton, Rosen \& Katz in New York.

De auteur bedankt Arne Grimme voor zijn commentaar op een eerdere versie van deze bijdrage.
}

bestaat. Vervolgens wordt kort besproken waarom in Nederland, anders dan in de Verenigde Staten, het openbaar bod de standaard toegepaste overnamestructuur voor beursgenoteerde vennootschappen is. $\mathrm{Na}$ een schets van de opkomst en ontwikkeling van de pre-wired back-end structuur zal vervolgens worden ingegaan op de normering daarvan. Daarbij zal in het bijzonder aandacht worden besteed aan de ratio achter de additionele vereisten waaraan pre-wired back-ends in de praktijk doorgaans moeten voldoen.

\section{Delaware: steun van meerderheid van het kapitaal voldoende voor verkrijging honderd procent eigendom}

\subsection{De one-step merger}

Een ruime meerderheid van de overnames van beursgenoteerde vennootschappen in de Verenigde Staten heeft de vorm van een juridische fusie, ook wel de one-step merger genoemd. ${ }^{1} \mathrm{De}$ meest toegepaste variant daarvan, de reverse triangular merger, houdt kort gezegd in dat een dochtervennootschap van de bieder wegfuseert in de doelvennootschap, ten gevolge waarvan de doelvennootschap honderd procent dochtermaatschappij wordt van de bieder. Anders dan bij een Nederlandse fusie, kunnen partijen in de Verenigde Staten vrijelijk bepalen welke vorm de vergoeding heeft die de aandeelhouders van de doelvennootschap ontvangen in ruil voor hun aandelen. ${ }^{2} Z_{0}$ kan deze vergoeding bijvoorbeeld bestaan uit cash, aandelen in de bieder, of een mix van het voorgaande. De fusie dient te worden goedgekeurd door de board of directors van (onder meer) de doelvennootschap en kan daarom niet worden gebruikt bij vijandige overnames. ${ }^{3}$ Daarnaast moet de fusie worden goedgekeurd door de aandeelhouders van de doelvennootschap, welk besluit onder het recht van de meeste staten, waaronder

1. In 2018 vonden er 213 one-step mergers plaats met een beursgenoteerde doelvennootschap, met een totale waarde van ongeveer USD 872 miljard (volgens Deal Point Data).

2. Fusies worden in de VS in het statelijke recht geregeld. Uit art. 251(b)(5) van de Delaware General Corporation Law (DGCL) blijkt bijv. dat de vergoeding onder meer kan bestaan uit cash, property or shares or other securities of the surviving or resulting corporation.

3. Art. 251(b) DGCL. 


\section{Maandblad}

Ondernemingsrecht

dat van Delaware, dient te worden genomen met een volstrekte meerderheid van het uitstaande kapitaal. ${ }^{4}$

Het voordeel van deze transactiestructuur is evident: de bieder wordt door effectuering van de fusie in één stap direct honderd procent eigenaar van de doelvennootschap. Hij behoeft daartoe slechts een aandeelhoudersbesluit bij meerderheid van het uitstaande kapitaal. Door de totstandkoming van de fusie worden alle aandeelhouders meegetrokken in de transactie, ongeacht of zij die steunen. Men zou het een wettelijk dragalong recht van de meerderheid kunnen noemen. Vanwege dit voordeel wordt deze transactiestructuur ook regelmatig gebruikt bij overnames van niet-beursgenoteerde vennootschappen met veel aandeelhouders. Niet alleen omdat het soms onpraktisch kan zijn om met iedere individuele aandeelhouder te onderhandelen, maar ook om zo het risico weg te nemen dat een minderheidsaandeelhouder hold-out value probeert te onttrekken door op onredelijke gronden zijn medewerking aan de transactie te onthouden.

\subsection{De two-step merger}

Omdat de voor een one-step merger benodigde documentatie dient te worden voorgelegd aan de Securities Exchange Commission (SEC), kan er soms veel tijd verstrijken na het tekenen van de merger agreement voordat de aandeelhouders over de transactie kunnen stemmen. ${ }^{5}$ Daarom wordt bij overnames van Amerikaanse beursvennootschappen soms gekozen voor de snellere two-step merger. ${ }^{6}$ Met name bij cash-deals kan deze structuur een tijdsvoordeel opleveren. ${ }^{7}$ Deze alternatieve structuur houdt in dat de bieder een openbaar bod doet op de aandelen van de doelvennootschap, dat na gestanddoening direct wordt gevolgd door een short-form merger van de doelvennootschap met (het acquisitievehikel van) de bieder. Ten gevolge van die fusie worden de aandelen van de overblijvende minderheidsaandeelhouders omgezet in een recht op dezelfde

4. Art. 251(c) DGCL. Dit is een aanzienlijk strenger vereiste dan de vereiste meerderheid voor een Nederlands fusiebesluit, dat in de regel kan worden genomen met slechts een meerderheid van de uitgebrachte stemmen, of, als minder dan de helft van het geplaatst kapitaal op de vergadering vertegenwoordigd is, met een meerderheid van ten minste twee derde van de uitgebrachte stemmen (zie art. 2:317 jo. art. 2:330 BW). Bij de Amerikaanse fusie geldt een niet-uitgebrachte stem dus de facto als een stem tegen, terwijl dat niet zo is bij de Nederlandse fusie.

5. De proxy statement waarmee de doelvennootschap haar aandeelhouders uitnodigt om tijdens een vergadering over de merger agreement en daaruit voortvloeiende transacties te stemmen, dient door de SEC te worden 'gecleared', wat tussen de drie weken en een aantal maanden kan duren. De proxy statement kan pas aan de aandeelhouders worden gestuurd, en de oproepingstermijn kan dus pas gaan lopen, nadat dit SEC-proces is afgerond.

6. In 2018 vonden er 26 two-step mergers plaats met een totale waarde van ongeveer USD 62 miljard (volgens Deal Point Data).

7. Als de bieder in aandelen betaalt, wat in de VS regelmatig het geval is, zal de registration statement/prospectus voor de uitgifte van die aandelen ook aan de SEC moeten worden voorgelegd, zodat het tijdsvoordeel soms verloren kan gaan. Daarnaast geldt dat een one-step merger vaak aantrekkelijker is als er goedkeuring benodigd is van andere autoriteiten en de verwachting bestaat dat dat goedkeuringsproces langer zal duren dan het SEC-proces. Zie nader over de voor- en nadelen van de one-step merger en two-step merger: Wachtell, Lipton, Rosen \& Katz, Takeover Law and Practice, 2019 (hierna: Wachtell 2019), par. IV.B. vergoeding als onder het bod werd aangeboden. Onder het recht van Delaware is het mogelijk om direct na de gestanddoening van het bod een dergelijke squeeze-out merger te effectueren, zonder dat er een algemene vergadering hoeft te worden bijeengeroepen om daarover te stemmen. Op grond van artikel 251(h) van de Delaware General Corporation Law (DGCL) kan direct worden doorgepakt, mits de merger agreement daarin uitdrukkelijk voorziet, ${ }^{8}$ de bieder na de gestanddoening van het bod meer dan de helft van de aandelen in de doelvennootschap houdt en de vergoeding onder de fusie gelijk is aan die onder het bod. ${ }^{9}$

\subsection{Beperkte verzetsmogelijkheden minderheidsaandeelhouders}

Kortom, onder het recht van Delaware heeft de bieder slechts de steun nodig van de board of directors en een meerderheid van het uitstaande kapitaal van de doelvennootschap om honderd procent eigenaar te worden, ongeacht de gekozen transactiestructuur. Behoudens andersluidende afspraken, kunnen minderheidsaandeelhouders niet voorkomen dat zij daardoor tegen hun zin hun aandelen in de doelvennootschap verliezen.

Wel kunnen minderheidsaandeelhouders soms gebruik maken van hun wettelijke appraisal rights, wat inhoudt dat zij de rechter vragen om de prijs van hun aandelen vast te stellen omdat de door de bieder geboden vergoeding te laag zou zijn. Zo kunnen in Delaware aandeelhouders die tegen een one-step merger hebben gestemd, of die na een bod door een short-form merger worden uitgestoten, de Court of Chancery verzoeken de fair value van hun aandelen vast te stellen. ${ }^{10}$ Kort gezegd heeft dit tot gevolg dat die aandeelhouders niet worden meegetrokken in de transactie, maar een vordering op de doelvennootschap krijgen voor het bedrag van de fair value van hun aandelen. In die fair value mag het effect van de transactie op de waarde van de aandelen niet worden verdisconteerd. ${ }^{11} \mathrm{Uit}$ recente rechtspraak blijkt dat de fair value ook lager kan liggen dan de deal price. ${ }^{12}$

De appraisal remedy is echter niet altijd beschikbaar. Zo hebben aandeelhouders in Delaware geen appraisal right als de doelvennootschap beursgenoteerd is en de vergoeding onder de fusie bestaat uit uitsluitend aandelen in een andere beursgenoteerde partij. In andere staten, zoals Arizona, bestaat er überhaupt geen appraisal right als de doelvennootschap beursgenoteerd is, dus ook niet als de vergoeding geheel of gedeeltelijk in cash luidt. ${ }^{13}$ De gedachte hierachter is dat de beurskoers

8. Aangezien de short-form merger alleen mogelijk is als die uitdrukkelijk is overeengekomen met de doelvennootschap voorafgaande aan het bod, kunnen vijandige bieders daarvan geen gebruik maken.

9. Zie art. 251(h)(1) DGCL. Voorheen gold dat de bieder ten minste $90 \%$ van de aandelen moest houden na het bod om de short-form merger te mogen implementeren, maar die grens is in 2013 verlaagd naar meer dan 50\%. Zie hierover Wachtell 2019, par. IV.B.2.

10. Art. 262 DGCL.

11. Art. 262(h) DGCL.

12. Zie bijv. Merlin Partners, LP v. SWS Group, Inc., 2018 WL 1037477 (Del. Feb. 23, 2018).

13. Art. 10-1302(D) AZ Rev Stat. 
van de aandelen in de doelvennootschap een natuurlijke reflectie is van de fair value daarvan, en er dus geen behoefte bestaat aan een appraisal remedy als er een transactie plaatsvindt tegen een premie boven die koers. ${ }^{14}$ In weer andere staten zijn appraisal rights slechts beschikbaar als er sprake is van een potential conflict of interest, of kunnen de appraisal rights zelfs geheel worden weggeschreven in het charter van de vennootschap. ${ }^{15}$

Naast het instellen van appraisal claims, kunnen minderheidsaandeelhouders die menen benadeeld te worden door een change of control-transactie soms schadevergoeding vorderen op grond van schending van fiduciary duties door de betrokken partijen. Dit geldt met name als er sprake is van transacties met controlerende partijen, zoals grootaandeelhouders. Net als bij de appraisal remedy gaat het hierbij niet om de vraag of de aandeelhouder ten onrechte van zijn aandelen is ontdaan, maar met name of hij daarvoor voldoende is gecompenseerd. ${ }^{16}$

\section{Overnamestructuren in Nederland}

Anders dan in de Verenigde Staten, speelt de juridische (driehoeks)fusie nauwelijks een rol bij overnames van Nederlandse beursvennootschappen. Dit is in belangrijke mate een gevolg van de beperkingen die in Nederland aan die rechtsfiguur inherent zijn. Zo kan de bieder bij een Nederlandse juridische fusie niet ongeclausuleerd ${ }^{17}$ betalen in cash (of bijvoorbeeld contingent value rights), maar alleen in aandelen in zijn eigen kapitaal of van een groepsmaatschappij. Deze beperking, die overigens een Europese oorsprong heeft, ${ }^{18}$ maakt de juridische fusie dus ongeschikt als de bieder geheel of gedeeltelijk wenst te betalen in cash. In de Nederlandse public M\&A-praktijk betalen kopers slechts zelden met (uitsluitend of hoofdzakelijk) aandelen, en daarom wordt de juridische fusie bij overnames van Nederlandse beursvennootschappen weinig toege-

14. In vergelijkbare zin overwoog Manning reeds in 1962: 'Appraisal should be considered an economic substitute for the stock exchange and its use should be limited to situations in which the exchange, or some kind of a reasonable market, is not available.' Zie B. Manning, The shareholder's appraisal remedy: An essay for Frank Coker, The Yale Law Journal 1962, afl. 2, p. 62.

15. Zoals in Massachusetts respectievelijk Maryland.

16. '[T] he emphasis in terms of protection of minorities is not based on an absolute right for minorities to remain shareholders, but rather on ensuring that the cashed-out investors obtain the fair value of their shares', zie M. Ventoruzzo, Freeze-outs: Transcontinental analysis and reform proposals, Virginia Journal of International Law 2010/841, p. 903. 'Appraisal rights were created to ensure fair compensation for shareholders who involuntarily sold their shares in a merger', zie M.E. Miehl, The cost of appraisal rights: How to restore certainty in Delaware mergers, Georgia Law Review 2018, p. 651.

17. Art. 2:325 lid 2 jo. art. 2:311 lid 2 BW limiteert een cash-vergoeding onder een fusie tot maximaal $10 \%$ van de nominale waarde van de toegekende aandelen.

18. De beperking vloeit voort uit art. 3 en 4 van de Fusierichtlijn (2011/35/ EU). Zie hierover T. Vos, 'Baby, it's cold outside...' - A comparative and economic analysis of freeze-outs of minority shareholders, European Company and Financial Law Review 2017, afl. 1, par. IV.1.

19. Precedenten zijn de fusie tussen HITT N.V. en Q.P.S. Holding B.V. in 2007 en die tussen Bever Holding N.V. en Bonavella Holding B.V. in 2007. past. ${ }^{19}$ Hetzelfde geldt overigens voor de grensoverschrijdende juridische fusie. ${ }^{20}$

De activa/passiva-transactie biedt meer flexibiliteit. In het verleden is die structuur dan ook meer dan eens toegepast om de onderneming van een beursgenoteerde vennootschap over te nemen. ${ }^{21}$ Een aantrekkelijk aspect van de activa/passiva-transactie vergeleken met het openbaar bod is dat deze op grond van artikel 2:107a BW, behoudens gekwalificeerde vereisten in de statuten, slechts dient te worden goedgekeurd door een besluit van de algemene vergadering, genomen met een volstrekte meerderheid van de uitgebrachte stemmen. Na de totstandkoming van dat meerderheidsbesluit kan de gehele onderneming aan de koper worden verkocht en overgedragen, en worden besloten tot uitkering van de verkoopopbrengst aan de aandeelhouders van de doelvennootschap.

Er kleven echter ook nadelen aan deze structuur. Zo kan de activa/passiva-transactie fiscaal nadelig zijn, bijvoorbeeld voor (buitenlandse) aandeelhouders vanwege de in te houden dividendbelasting op de uitkering van de verkoopopbrengst. Daarnaast wordt er regelmatig op gewezen dat een activa/passivatransactie bewerkelijk is omdat alle individuele vermogensbestanddelen zullen moeten worden overgedragen, de overdracht van contracten en licenties onder omstandigheden niet mogelijk zal zijn en eventuele achterblijvende verplichtingen op het niveau van de doelvennootschap een belemmering kunnen vormen bij de uitkering van de verkoopopbrengst. ${ }^{22}$ Een belangrijk deel van deze laatste nadelen kan echter vrij eenvoudig worden ondervangen, zie daarover paragraaf 5.1 hierna.

Het gevolg van voorgaande beperkingen en nadelen is dat het overgrote deel van de overnames van Nederlandse beursvennootschappen plaatsvindt door middel van een openbaar bod. In de praktijk worden de juridische fusie en activa/passivatransactie pas overwogen als bijzondere omstandigheden ertoe nopen te zoeken naar alternatieven voor de 'standaard' openbaar-bodstructuur. ${ }^{23}$

20. Een precedent van een grensoverschrijdende fusie met een beursgenoteerde NV betreft de fusie tussen Koninklijke Ahold N.V. en Delhaize Group S.A. in 2016. Ook het uittreedrecht in art. 2:333h BW maakt de grensoverschrijdende juridische fusie in sommige gevallen een onaantrekkelijke optie.

21. Zo verkochten de volgende beursvennootschappen hun gehele onderneming door een stand-alone activa/passiva-transactie: Invensys N.V. in 2000, Rodamco North America N.V. in 2002, New Skies Satellites N.V. in 2004, Metron Technology N.V. in 2004, Equant N.V. in 2005, Super de Boer N.V. in 2009, Amsterdam Molecular Therapeutics Holding NV in 2012, Qurius N.V. in 2012, en Roto Smeets N.V. in 2015.

22. Zie bijv. P.H.C. van Leeuwen, 'De activa/passiva-transactie als uitstotingsmethode', V\&O 2011, afl. 7-8, p. 137-142, p. 141.

23. Zie C.J.C. de Brauw, Overnames van beursvennootschappen, Deventer: Wolters Kluwer 2017, p. 883. 


\section{Opkomst van back-end structuren in Nederland}

\subsection{Beperkingen wettelijke uitkoopprocedure}

Er zijn altijd aandeelhouders die, vanwege uiteenlopende redenen, hun aandelen niet aanbieden onder een openbaar bod. ${ }^{24}$ Vaak geven bieders daarom na gestanddoening van het bod de resterende aandeelhouders de mogelijkheid om alsnog hun stukken aan te bieden tegen gelijke voorwaarden gedurende een na-aanmeldingstermijn. ${ }^{25}$ Die extra kans resulteert er regelmatig in dat de bieder alsnog een belangrijke pluk aandelen uit de markt haalt, maar neemt niet weg dat een bieder zich na een openbaar bod altijd geconfronteerd ziet met een resterende minderheid. ${ }^{26}$ De wet voorziet daarom in de mogelijkheid om deze minderheid na het bod uit te kopen. ${ }^{27}$ Over die regeling valt veel te zeggen, maar kort gezegd biedt zij niet altijd een adequate oplossing voor bieders die honderd procent controle verlangen. De belangrijkste beperking is dat de uitkoopprocedure alleen openstaat voor bieders die ten minste 95\% van het geplaatst kapitaal en de stemrechten houden na gestanddoening van het bod. ${ }^{28}$ Maar ook als die grens wordt gehaald, zijn er beperkingen. Een uitkoopprocedure duurt in de regel ten minste enkele maanden, waarin de bieder beperkt wordt in zijn mogelijkheden om de acquisitiefinanciering ten laste van de doelvennootschap te brengen, intragroeptransacties uitsluitend at arm's length zal kunnen implementeren en zich geconfronteerd ziet met de overige nadelen die inherent zijn aan een minderheidsparticipatie (zie par. 7.1). Daarnaast verplicht de uitkoopprocedure de bieder om de minderheidsaandeelhouders in cash te betalen, ${ }^{29}$ wat een obstakel kan zijn voor bieders die nu juist voor een ruilbod hebben gekozen omdat zij geen liquide middelen willen of kunnen aanspreken voor de transactie. ${ }^{30}$

Vanwege deze nadelen zijn er in de praktijk alternatieve manieren ontwikkeld om volledige controle te verwerven na een openbaar bod. Die structuren zijn inmiddels zo ver door-

24. Dit kan een bewuste keuze zijn van bijv. een activistische aandeelhouder, zoals het geval was bij het bod van Canon op Océ N.V. in 2009, maar ook van onbekendheid van bepaalde (buitenlandse) aandeelhouders met het bod of de werking daarvan; zie hierover, naar aanleiding van het bod van JAB Benckiser op D.E. Master Blenders in 2013, L. Scheepbouwer, Postclosing herstructurering: goede ideeën beginnen met goede koffie, V\&O 2013, afl. 12, p. 205.

25. Kortheidshalve zal in de rest van deze bijdrage steeds worden gesproken over 'na gestanddoening' waar strikt genomen bedoeld wordt 'na gestanddoening of na een eventuele na-aanmeldingstermijn'.

26. De in art. 5:59 Wft vervatte best price rule makt het voor de bieder onmogelijk om direct na gestanddoening die aandelen alsnog te verwerven door onderhandse transacties tegen een prijs die hoger ligt dan de biedprijs.

27. Art. 2:92a en 2:359c BW. Zie hierover uitgebreid T. Salemink, Uitkoop van minderheidsaandeelhouders (VDHI nr. 125), Deventer: Kluwer 2014.

28. Uitkoop op grond van art. 2:92a BW vereist $95 \%$ of meer van uitsluitend het geplaatst kapitaal; uitstoting op basis van art. 2:359c BW vereist 95\% of meer van het geplaatst kapitaal en van de stemrechten en - indien er meerdere soorten aandelen zijn - 95\% van iedere soort van die aandelen.

29. Zie art. 2:359c lid 6 BW.

30. Waarbij zij opgemerkt dat - zoals aangegeven in par. 3 - het ruilbod in Nederland veel minder vaak voorkomt dan in de VS. ontwikkeld, dat zij een antwoord bieden op alle hierboven genoemde beperkingen van de wettelijke uitkoopprocedure. De meest recente back-end constructies bieden de mogelijkheid om (1) ook bij minder dan 95\% aanmelding volledige controle te verwerven, (2) de integratie direct na de gestanddoening van het bod te effectueren en (3) de resterende minderheidsaandeelhouders te vergoeden in andere vormen dan cash.

\subsection{Van de back-end-fusie...}

De eerste Nederlandse back-end structuren doken op in transactiedocumentatie in de tweede helft van de jaren negentig en hadden meestal de vorm van een juridische fusie, waarschijnlijk geïnspireerd door de Amerikaanse squeeze-out merger. ${ }^{31}$ Door na gestanddoening van het bod de doelvennootschap te laten wegfuseren in een groepsmaatschappij van de bieder, kon soms het belang van de minderheidsaandeelhouders door verwatering onder de $5 \%$ worden gebracht, zodat alsnog de wettelijke uitkoopprocedure kon worden gestart. ${ }^{32}$ Daarnaast werd de fusie gebruikt om de minderheid simpelweg te verplaatsen naar het kapitaal van de $\left(\right.$ meestal $\left.{ }^{33}\right)$ beursgenoteerde bieder. ${ }^{34}$ De juridische fusie wordt tegenwoordig niet zo vaak meer gebruikt als back-end structuur, maar is in 2017 nog wel op deze manier toegepast bij de overname van Delta Lloyd N.V. door NN Group N.V. Omdat NN Group na gestanddoening van haar bod $93,3 \%$ in Delta Lloyd hield, heeft zij een maand later een juridische driehoeksfusie geëffectueerd, waardoor de aandelen van de overblijvende minderheid werden omgeruild voor aandelen in de beursgenoteerde NN Group. De resterende minderheidsaandeelhouders ontvingen via de back-end dus (beursgenoteerde) aandelen, terwijl de aandeelhouders die wel op het bod waren ingegaan in cash betaald werden.

Sinds 2008 is de fusie-back-end ook mogelijk als de beursgenoteerde bieder is opgericht onder het recht van een andere EUlidstaat, door gebruik te maken van de grensoverschrijdende fusie. $^{35}$ Toen het Franse Klépierre S.A. in 2014 een ruilbod deed op Corio N.V., hield zij na gestanddoening 93,6\% van het geplaatst kapitaal. Direct na gestanddoening fuseerde Corio weg in Klépierre, waarbij de overgebleven minderheids-

31. Zie hierover G.C. Meijer, Over de juridische fusie na een openbaar bod, V\&O 2005, afl. 10, p. 166-169 en S.J.H.M. Berendsen \& S.C.M. van Thiel, Shell: pseudo-uitkoop van minderheidsaandeelhouders bij juridische fusie, TOP 2008, afl. 3, p. 92-98.

32. Zie bijv. de fusie van Versatel en Tele2 Finance, waarover meer in par. 7.4 hierna.

33. Zo werd de juridische fusie gebruikt om na het bod van New Lake Direct Investments B.V. (Alpinvest) op Delft Instruments N.V. de resterende minderheid aandelen toe te kennen in de niet-beursgenoteerde bieder.

34. De juridische fusie is bijv. op deze wijze als back-end toegepast door beursgenoteerde bieders, in 2008 na het bod van Randstad Holding N.V. op Vedior N.V., in 2005 na het bod van KPN N.V. op SNT Group N.V., in 2004 na het bod van Getronics N.V. op PinkRoccade N.V., en in 1998 na het bod van Vendex N.V. op NV Koninklijke Bijenkorf Beheer KBB.

35. Zie R.H. Kleipool \& C.R. Nagtegaal, De grensoverschrijdende fusie als pre-wired herstructurering, TOP 2016, afl. 5 . 
aandeelhouders evenveel aandelen in Klépierre ontvingen als zij onder het ruilbod zouden hebben gekregen. ${ }^{36}$

\section{3 ... naar de back-end activa/passiva-transactie}

De afgelopen tien jaar heeft de activa/passiva-transactie het back-end-stokje van de juridische fusie overgenomen. ${ }^{37}$ Deze structuur heeft als voordeel dat de vergoeding van de minderheidsaandeelhouders iedere vorm kan hebben, en dus niet beperkt is tot aandelen in de bieder of een groepsmaatschappij daarvan. De activa/passiva-structuur kan daarom bijvoorbeeld ook worden ingezet om de resterende minderheid te betalen in cash of met aandelen in een bieder die is opgericht onder het recht van een jurisdictie buiten de EU.

De activa/passiva-back-end bestaat in de kern uit de volgende stappen. Na gestanddoening van het bod verkoopt de doelvennootschap al haar activa en passiva aan (een groepsmaatschappij van) de bieder en vindt direct de overdracht daarvan plaats. De bieder betaalt voor die activa en passiva een prijs die gelijk is aan de biedprijs voor alle aandelen, maar blijft een deel van de koopprijs schuldig gelijk aan het percentage door hem zelf in de doelvennootschap gehouden aandelen. De bieder betaalt dus alleen daadwerkelijk de koopprijs voor zover er na het bod nog minderheidsaandeelhouders resteren. Vervolgens wordt de doelvennootschap ontbonden en keert zij bij wijze van vereffeningsuitkering bij voorbaat de koopprijs uit. ${ }^{38}$ Het deel van die uitkering dat aan de bieder als meerderheidsaandeelhouder toekomt, wordt verrekend met de schuldbekentenis, en de minderheidsaandeelhouders ontvangen de daadwerkelijk betaalde middelen. Het resultaat is dat de minderheidsaandeelhouders dezelfde vergoeding ontvangen die zij hadden gekregen als zij hun aandelen hadden aangeboden onder het bod, minus fiscale inhoudingen.

\section{Verdere verfijning van activa/passiva-back-end}

\subsection{Interne herstructurering voorafgaande aan actival passiva-back-end}

In recente activa/passiva-transacties is een extra stap geïntroduceerd om de in paragraaf 3 besproken nadelen weg te nemen die inherent zijn aan een overdracht van activa en passiva. ${ }^{39}$ Deze verfijning is ook voorgesteld in de activa/passiva-backend in het recent aangekondigde bod van Saxo Bank N.V. op Binckbank N.V. ${ }^{40}$ De extra stap houdt in dat de doelvennootschap eerst - dus na gestanddoening van het bod, maar voor-

36. De transactie kende een beperkte cash-component, aangezien art. 2:333h BW voorschrijft dat bij een grensoverschrijdende juridische fusie aandeelhouders van de verdwijnende vennootschap die tegen het fusievoorstel hebben gestemd, aanspraak kunnen maken op een schadeloosstelling. Daarnaast vond voorafgaande aan de gestanddoening van het bod een uitkering plaats door zowel Corio als Klépierre.

37. Zie over deze structuur ook De Brauw 2017, p. 739 e.v. en Van Leeuwen 2011.

38. Zie art. 2:23b lid $6 \mathrm{BW}$.

39. Bij mijn weten is deze verfijning voor het eerst toegepast in 2018 bij de overname van Chicago Bridge \& Iron Company N.V. door McDermott International, Inc. (waarover nader par. 8.3).

40. Zie het persbericht van 17 december 2018 . dat het hierboven besproken carrousel gaat draaien - een interne herstructurering doet. Deze herstructurering kan verschillende juridische vormen aannemen, zoals een interne driehoeksfusie, maar komt er in de kern op neer dat er een nieuw opgerichte topholding wordt geschoven tussen de doelvennootschap en haar aandeelhouders. ${ }^{41}$ Dit biedt als belangrijk voordeel dat vervolgens die nieuw opgerichte topholding, als enig aandeelhouder van de doelvennootschap, de doelvennootschap kan verkopen en overdragen aan de bieder. De acti$\mathrm{va} /$ passiva-transactie is in dat geval dus niets anders dan een verkoop van aandelen, zodat veel nadelen verbonden aan de overdracht van individuele activa, licenties en contractsoverneming worden voorkomen. Een ander belangrijk voordeel van deze structuur is dat de vereffeningsuitkering geschiedt door een nieuw opgerichte topholding, en dus niet door de oude beursgenoteerde NV, die doorgaans een lang verleden heeft en waar van alles in kan zitten, waaronder daadwerkelijke en potentiële verplichtingen. ${ }^{42}$

\subsection{Uitkoop van een cash box bij verwerving van 95\% of meer}

Als de bieder na gestanddoening van zijn bod $95 \%$ of meer van het uitstaande kapitaal in de doelvennootschap houdt, zal hij mogelijk nog steeds de voorkeur geven aan effectuering van de back-end boven het initiëren van de uitkoopprocedure vanwege de in paragraaf 4.1 genoemde redenen. In de eerste transacties waarin een back-end werd overeengekomen, werd doorgaans afgesproken dat de back-end uitsluitend gebruikt kon worden als de bieder minder dan 95\% zou verwerven. ${ }^{43}$ Die beperking wordt tegenwoordig niet meer standaard opgenomen. ${ }^{44}$ Reeds in 2010 werd gekozen voor de activa/passivaback-end bij de overname van Eurand N.V. door Axcan, terwijl Axcan na gestanddoening ruim 99\% van de aandelen in Eurand hield. En in 2014 koos Biomarin voor de activa/passiva-back-end, terwijl zij na haar bod op Prosensa 96,76\% van de

41. In eerdere transacties werd de nieuwe topholding niet opgericht door de doelvennootschap, maar door de bieder (zie bijv. het bod van JAB op D.E. Master Blender in 2013 en het bod van Andlinger \& Company op Crown van Gelder N.V. in 2015). Omdat de investment banks van de doelvennootschap bij die structuur doorgaans geen fairness opinion wilden afgeven ten aanzien van de back-end vergoeding, wordt de nieuwe topholding tegenwoordig meestal opgericht door de doelvennootschap.

42. De uitspraak van Rechtbank Rotterdam naar aanleiding van de uitkering na de activa/passiva-transactie tussen Jumbo Groep Holding B.V. en Super de Boer N.V. toont aan dat de uitkering van al het vermogen van de doelwitvennootschap tot bezwaren kan leiden, en dat de gebruikelijke vrijwaring van de bieder aan de doelwitvennootschap dit probleem mogelijk niet oplost (Rb. Rotterdam 24 april 2013, RO 2013/58, r.o. 7.18; in deze procedure stond overigens niet de uitkering zelf centraal, maar de communicatie aan de markt over de transactie en het lekken van koersgevoelige informatie).

43. Zie bijv. in het biedingsbericht van Johnson \& Johnson in het kader van haar bod in 2010 op Crucell N.V.: 'If the Offer is declared unconditional (gestand wordt gedaan) and at least $95 \%$ of the issued and outstanding Shares have been acquired by the Offeror, then the Offeror will acquire the remaining Shares not tendered by means of buy-out proceedings (uitkoopprocedure) or takeover buy-out proceedings.'

44. In het bod van NN Group op Delta Lloyd in 2017 was wel nog bepaald dat de back-end-fusie alleen openstond als NN Group onder de $95 \%$ zou eindigen. 


\section{Maandblad}

Ondernemingsrecht

aandelen hield. In die laatste transactie bestond de vergoeding onder het bod uit een mix van cash en contingent value rights, ${ }^{45}$ en zou de uitkoopprocedure waarschijnlijk tot ingewikkelde waarderingsvraagstukken hebben geleid omdat de contingent value rights contant zouden moeten worden gemaakt in het kader van de vaststelling van de uitkoopprijs.

Hoewel sommige auteurs de wettelijke uitkoopprocedure de 'koninklijke route' noemen, ${ }^{46}$ bestaat er geen verplichting voor een bieder die $95 \%$ of meer heeft verworven om van die wettelijke faciliteit gebruik te maken. Zo heeft de Ondernemingskamer in de Versatel-beschikking overwogen dat de uitkoopprocedure bedoeld is om het belang van een meerderheidsaandeelhouder te dienen, zodat er geen sprake is van ontduiking van die regeling als de meerderheidsaandeelhouder daarvan geen gebruik maakt. ${ }^{47}$ Dat neemt niet weg dat de route van de activa/passiva-back-end nadelen kan meebrengen voor de resterende aandeelhouders. Ook als de liquidatie-uitkering in de back-end gelijk is aan de uitkoopprijs die door de rechter zou zijn vastgesteld, zal de nettovergoeding in de backend soms lager zijn omdat op de vereffeningsuitkering dividendbelasting zal moeten worden ingehouden die niet alle aandeelhouders kunnen terugvragen of verrekenen. ${ }^{48}$ In het bod dat Qualcomm, Inc. in 2016 deed op NXP Semiconductors N.V. is op dit punt een middenweg bewandeld: na gestanddoening van het bod zou een activa/passiva-transactie plaatsvinden, maar als Qualcomm na het bod $95 \%$ of meer zou houden, zou daarop geen vereffeningsuitkering volgen, maar een uitkoopprocedure. Die uitkoopprocedure zou dus zien op de aandelen in de doelvennootschap die op dat moment niets anders meer zou houden dan de koopprijs voor de activa en passiva. Deze uitkoop van een 'cash box-vennootschap' biedt mogelijk the best of both worlds: de bieder heeft direct honderd procent controle over de onderneming, terwijl de minderheidsaandeelhouders op de wettelijk gefaciliteerde wijze worden uitgestoten. ${ }^{49}$

\section{De pre-wired back-end}

\subsection{Goedkeuring back-end voorafgaande aan gestanddoening}

De afgelopen jaren worden de hierboven besproken back-end structuren steeds vaker 'gepre-wired'. Dat houdt in dat de back-end transacties door de bieder en de doelvennootschap in

45. Contingent value rights zijn instrumenten die de houder recht geven op een additionele betaling, bijv. als bepaalde milestones worden behaald, vergelijkbaar met een earn-out in een private deal.

46. Zie bijv. C.J.C. de Brauw \& M.F. Noome, Vijf jaar pre-wired asset sale bij openbare biedingen, TOP 2015, afl. 7.

47. Hof Amsterdam (OK) 27 september 2005, JOR 2005/272 (Versatel), r.o. 3.15, waarover nader par. 7.4.

48. Zie hierover De Brauw 2017, p. 743 , voetnoot 53.

49. Het succes van deze structuur zal natuurlijk mede worden bepaald door de wijze waarop de OK met de uitkoopvordering zal omgaan. Zal bijv. nog aansluiting kunnen worden gezocht bij de biedprijs, en hoe wordt omgegaan met wisselkoersschommelingen en de peildatum? Nu de overname van NXP niet is doorgegaan, heeft de OK zich hier nog niet over hoeven buigen. de merger agreement gedetailleerd worden vastgelegd en vrijwel direct na de gestanddoening van het bod kunnen worden geëffectueerd, dus zonder dat er bijvoorbeeld nog een algemene vergadering hoeft te worden bijeengeroepen. Bij een goed voorbereide pre-wired back-end structuur kan meteen na gestanddoening van het bod op de spreekwoordelijke knop worden gedrukt om volledige controle te verwerven. Het prewired karakter schuilt er primair in dat reeds tijdens de informatieve BAVA over het bod de aandeelhoudersbesluiten worden genomen die noodzakelijk zijn voor de implementatie van de back-end transacties, zoals het fusiebesluit, 2:107a-besluit of liquidatiebesluit. ${ }^{50}$ Die besluiten worden dus voorafgaande aan de gestanddoening van het bod genomen, maar zijn uiteraard voorwaardelijk aan die gestanddoening. ${ }^{51}$ Een belangrijk verschil tussen de pre-wired back-end en 'reguliere' post-closing herstructureringen is dus dat de back-end wordt goedgekeurd door een algemene vergadering waarin de bieder (doorgaans) ${ }^{52}$ nog geen controlerende zeggenschap heeft.

\subsection{Meer deal certainty}

Voor de aandeelhouders die van plan zijn hun aandelen aan te bieden onder het bod, bestaat er een prikkel om voor de backend-besluiten te stemmen, omdat het aannemen daarvan de kans op een succesvol bod vergroot. Bieders die honderd procent controle verlangen, nemen doorgaans in hun bod de voorwaarde op dat zij na gestanddoening een bepaald minimumpercentage van de aandelen in de doelvennootschap zullen houden. Dit percentage is meestal 95\%, omdat de bieder daarmee de wettelijke uitkoopprocedure kan starten. In transacties waarin aan de algemene vergadering een pre-wired backend structuur wordt voorgelegd, zijn bieders bereid dit minimumpercentage aanzienlijk te verlagen (bijvoorbeeld naar $80 \%$ - zie par. 8.2 hierna). In aanvulling op de genoemde 95\%-voorwaarde nemen bieders dan op dat zij het bod reeds gestand zullen doen bij een lager percentage als de algemene vergadering de back-end-besluiten heeft aangenomen. Een prewired back-end vergroot kortom de kans dat het aangekondigde bod succesvol zal zijn, en deze toename in deal certainty is doorgaans in het belang van de bieder, de doelvennootschap en de aandeelhouders die hun aandelen wensen te vervreemden.

Het is niet ongebruikelijk dat de bieder tevens als voorwaarde in zijn bod opneemt dat de algemene vergadering van de doelvennootschap alle met het bod samenhangende besluiten heeft aangenomen. ${ }^{53}$ De pre-wired back-end-besluiten vallen doorgaans niet onder die voorwaarde, zodat de bieder ook

50. Zie art. 18 lid 1 Bob Wft.

51. De pre-wired back-end wordt daarnaast vaak voorwaardelijk gemaakt aan het behalen van een aanmeldingsdrempel, zie daarover nader par. 8.2 hierna.

52. Uiteraard is het mogelijk dat de bieder reeds voorafgaande an het bod, bijv. ten gevolge van stakebuilding, een significant belang in de doelwitvennootschap houdt.

53. Zie daarover nader A. Grimme, Deal protection in public M\&A, par. 8.4 (binnenkort te verschijnen in de Geschriften vanwege de Vereniging Corporate Litigation 2018-2019). 
gehouden is het bod gestand te doen als de 95\%-drempel wordt behaald maar de back-end-besluiten niet zijn aangenomen. Er is evenwel een aantal precedenten waarin ook het aannemen van de back-end-besluitvorming een ongeclausuleerde voorwaarde betrof, omdat de bieder ook boven de $95 \%$ ervan verzekerd wilde zijn dat hij de back-end kon implementeren. ${ }^{54}$

\subsection{Prikkel om aan te bieden}

De pre-wired back-end heeft ook een effect op de aandeelhouders die het bod niet steunen of om andere redenen niet voornemens zijn hun aandelen daaronder aan te bieden. De prewired back-end wordt in het biedingsbericht duidelijk aan de aandeelhouders gecommuniceerd, zodat zij weten dat als zij niet op het bod ingaan, de kans aanzienlijk is dat zij alsnog hun aandelen in de doelvennootschap zullen verliezen ten gevolge van de back-end, voor een mogelijk ongunstigere nettoprijs (zie par. 5.2 over de fiscale nadelen aan de back-end uitkering). Dit vormt een prikkel voor die aandeelhouders om hun aandelen toch maar aan te bieden. In veel gevallen is implementatie van de pre-wired back-end daarom uiteindelijk helemaal niet nodig. Van de bijna twintig deals met een prewired back-end sinds 2010 werd bij mijn weten slechts in zes gevallen de back-end ook daadwerkelijk geïmplementeerd, ${ }^{55}$ die dus in twee gevallen niet eens noodzakelijk was omdat de bieder genoeg aandelen hield om een uitkoopprocedure te starten.

Om te voorkomen dat het voorgaande leidt tot een oneigenlijke druk op de aandeelhouders om hun stukken aan te bieden, zullen het bestuur en de raad van commissarissen van de doelvennootschap bij een bod met een pre-wired backend, behoudens bijzondere omstandigheden, mijns inziens doorgaans willen bedingen dat er na gestanddoening van het bod een na-aanmeldingstermijn volgt. Deze termijn dient ertoe de aandeelhouders die het bod niet steunen alsnog een (fiscaal gunstige) exit te bieden nadat duidelijk is geworden dat het bod gestand wordt gedaan en de back-end geïmplementeerd zal worden. Zonder deze laatste kans zou de aandeelhouder die het bod niet steunt, moeten kiezen tussen twee kwaden: bied ik mijn aandelen niet aan, met het wezenlijke risico dat ik ze direct na gestanddoening van het bod alsnog verlies tegen een lagere nettovergoeding, of bied ik mijn aandelen wel

54. Zie bijv. Biomarin/Prosensa in 2014 en McDermott/CB\&I in 2018 (zij het dat bij die laatste transactie geen sprake was van een klassieke backend, zie par. 8.3 hierna).

55. Te weten bij Eurand/Axcan in 2010, Klépierre/Corio in 2014, Biomarin/Prosensa in 2014, Andlinger/Crown van Gelder in 2015, NN Group/Delta Lloyd in 2017 en McDermott/CB\&I in 2018 (zij het dat bij die laatste transactie geen sprake was van een klassieke back-end, zie par. 8.3 hierna). aan, waardoor ik ongewild bijdraag aan de kans dat het bod gestand zal worden gedaan ${ }^{56}$

\section{Normering van back-end structuren}

\subsection{Afweging van belangen}

Van een afstand beschouwd kan een pre-wired back-end structuur er agressief uitzien. De aandeelhouder die besloten heeft om niet op het bod van de bieder in te gaan, wordt door toepassing van de back-end de facto het bod alsnog opgedrongen. Tegen zijn zin verliest de aandeelhouder zijn deelname in de doelvennootschap tegen een prijs die hij niet heeft aanvaard. Anderzijds wordt breed onderkend dat er goede redenen zijn waarom een bieder honderd procent eigendom wenst te verkrijgen. Zo kan een voortdurende minderheidsparticipatie in de weg staan aan beëindiging van de beursnotering, de juridische en operationele integratie bemoeilijken en in de weg staan aan het creëren van een fiscale eenheid. Bovendien zal de bieder algemene vergaderingen moeten blijven organiseren, moeten blijven voldoen aan openbaarmakingsverplichtingen, mogelijk niet het door hem gewenste dividendbeleid kunnen voeren en de governance van de vennootschap moeten afstemmen op de aanwezigheid van minderheidsaandeelhouders. Het is daarom goed mogelijk dat het belang van de vennootschap en de door haar gedreven onderneming, en van alle daarbij betrokken stakeholders, gediend is bij een 'honderd procent eigendom'-situatie. ${ }^{57}$ Veel potentiële bieders zullen bovendien niet eens bereid zijn om een bod uit te brengen als niet op voorhand een zekere route naar honderd procent eigendom kan worden uitgestippeld.

Het belang van de minderheidsaandeelhouder bij voortduring van zijn aandeelhouderschap na een openbaar bod zal kortom moeten worden afgewogen tegen het belang van de bieder en van de doelvennootschap bij verkrijging van honderd procent, en dus tevens tegen het belang van de doelvennootschap bij het doorgaan van de transactie. Het is helder dat in Delaware die afweging in het voordeel van de bieder en doelvennootschap uitvalt als zij op de steun kunnen rekenen van meer dan

56. Een obiter dictum van de $\mathrm{OK}$ in de Versatel-procedure lijkt overigens te impliceren dat het bestuur en de $\mathrm{RvC}$ geen rekening hoeven te houden met de fiscale gevolgen van de back-end (Hof Amsterdam (OK) 27 september 2005, JOR 2005/272 (Versatel), r.o. 3.13). De OK overwoog dat de mogelijkheid van de minderheidsaandeelhouders om tot verrekening dan wel teruggave van dividendbelasting te komen een persoonlijke omstandigheid is waar de doelvennootschap en bieder in beginsel geen rekening mee hoeven te houden. Dit deed zij naar aanleiding van de vraag of in het biedingsbericht tot uitdrukking had moeten worden gebracht dat er juist geen dividendbelasting zou hoeven worden ingehouden over een bepaalde post-closing uitkering, nu die gedekt werd door het fiscaal erkende agio. Ik betwijfel of de OK hier heeft willen zeggen dat het bestuur en de $\mathrm{RvC}$ van een doelwitvennootschap bij het aangaan van de transactie zonder meer het belang van de aandeelhouders bij een fiscaal gunstige structurering van de overname mogen negeren.

57. Zie hierover ook de Versatel-beschikking, waarover par. 7.4. 


\section{Maandblad}

Ondernemingsrecht

$50 \%$ van het kapitaal. ${ }^{58}$ Dit gegeven bepaalt dan ook in belangrijke mate de mindset van bieders en investeerders uit de Verenigde Staten (en overigens ook uit het Verenigd Koninkrijk). ${ }^{59}$ In Nederland lijkt echter minder duidelijkheid te bestaan op dit punt.

\subsection{Grenzen aan back-end structuren}

De Nederlandse wet stelt geen uitdrukkelijke grenzen aan het gebruik van back-end structuren. Sterker nog, de kern van een back-end structuur is nu juist dat partijen gebruik maken van de mogelijkheden die Boek $2 \mathrm{BW}$ hun biedt om tot het door hen beoogde resultaat te komen. Zolang de daarbij gehanteerde herstructureringsvormen aan alle technische regelen der kunst voldoen - denk aan besluitvorming ex artikel 2:317 jo. artikel 2:330 en/of 2:107a BW, verzetstermijnen, een accountantsverklaring ter zake van de ruilverhouding, enzovoort -, staat in beginsel niets aan de geldigheid van de structuur in de weg. Dat neemt natuurlijk niet weg dat partijen door gebruik te maken van hun wettelijke en statutaire bevoegdheden in het kader van een back-end in bijzondere gevallen in strijd kunnen handelen met hetgeen de redelijkheid en billijkheid vordert op grond van artikel 2:8 BW, onrechtmatig kunnen handelen, of zich als bestuurder schuldig kunnen maken aan onbehoorlijke taakvervulling of wanbeleid.

Back-end structuren hebben echter vooralsnog slechts beperkt aanleiding gegeven tot rechtspraak. De relevante jurisprudentie (zie hierna) is inmiddels meer dan tien jaar oud en ziet daarom uitsluitend op transacties waarin niet de activa/passiva-transactie, maar de juridische fusie als back-end werd gebruikt. Dat doet er niet aan af dat die rechtspraak ook relevante gezichtspunten bevat voor de thans veelgebruikte activa/ passiva-back-end en voor de ontwikkeling van toekomstige structuren.

\subsection{Back-ends in de lagere rechtspraak}

Zo betreft de Shell-beschikking van de Ondernemingskamer uit 2007 een treffend voorbeeld van een bieder die een stap te ver was gegaan om zich na een bod van de minderheid te kunnen ontdoen. ${ }^{60}$ Daarin oordeelde de Ondernemingskamer dat Shell op oneigenlijke wijze gebruik had gemaakt van de juridische fusie door de nominale waarde van de aandelen in de verkrijgende vennootschap dusdanig te verhogen dat krachtens de ruilverhouding alle resterende minderheidsaandeelhouders een cash-vergoeding ontvingen in plaats van aandelen in de

58. Zo noteerde Manning reeds in 1962 treffend: 'For nearly a century, our law has been opting consistently for mobility and the will of the group. It no longer seems feasible (or, it is significant to note, moral) to permit the objecting individual to stand in the way of a transaction approved (or at least not objected to) by a majority (or those acting in their name).' Zie Manning 1962, p. 230.

59. Aangezien men in het VK bij overnames van beursvennootschappen gebruik kan maken van het scheme of arrangement, waarin ook de aandeelhouders worden meegetrokken die tegen de transactie hebben gestemd, mits het scheme is goedgekeurd met de vereiste $75 \%$ meerderheid (per klasse) en rechterlijke goedkeuring heeft gekregen.

60. Hof Amsterdam (OK) 20 december 2007, JOR 2008/36 m.nt. Van der Korst, waarover Berendsen \& Van Thiel 2008 en Meijer 2005. verkrijgende vennootschap. Het 'aandelen voor aandelen'karakter van de juridische fusie werd daardoor dus omzeild. Het betrof hier echter een vrij extreem geval, ${ }^{61}$ zodat uit het oordeel van de Ondernemingskamer weinig algemene lessen kunnen worden getrokken over de grenzen aan back-end structuren. $^{62}$

De president van de Rechtbank Amsterdam sprak zich in 1999 wel in algemene bewoordingen uit over de back-endfusie. ${ }^{63}$ In een kort geding waarin een minderheidsaandeelhouder van $\mathrm{KBB}$ opkwam tegen de voorgenomen juridische fusie na het bod van Vendex, oordeelde de president dat de wens om niet langer belast te zijn met de aanwezigheid van een minderheidsaandeelhouder op zichzelf een rechtmatig motief kan zijn voor een juridische fusie, mits die bedoeling voldoende uit het biedingsbericht bleek. Een later door dezelfde minderheidsaandeelhouder bij de Rechtbank Amsterdam aangebrachte procedure onderstreept dat het daarbij vanzelfsprekend wel van belang is dat partijen voldoende onderzoek doen naar, en openheid betrachten over, de redelijkheid van de bij die fusie toegepaste ruilverhouding. ${ }^{64}$

\subsection{De caveats in de Versatel-beschikking}

In de Versatel-beschikkingen komt een genuanceerder beoordelingskader naar voren. ${ }^{65}$ In die zaak stond - kort gezegd de voorgenomen juridische fusie centraal die Tele2 na haar bod op Versatel wenste te implementeren om het belang van de minderheidsaandeelhouders tot onder de $5 \%$ te reduceren, zodat de uitkoopprocedure kon worden ingezet. Het argument van de daartegen in het geweer gekomen minderheidsaandeelhouders dat Tele2 en Versatel de uitkoopprocedure zouden omzeilen, werd door de Ondernemingskamer van tafel geveegd. ${ }^{66}$ De Ondernemingskamer benadrukte vervolgens dat 'de wens om niet bij voortduring belast te blijven met de aanwezigheid van minderheidsaandeelhouders op zichzelf legitiem is'. ${ }^{67}$

In cassatie overwoog de Hoge Raad dat 'met de mogelijkheid dat de vennootschap door fusie, splitsing of omzetting een gedaantewisseling kan ondergaan die tot gevolg heeft dat het belang van de minderheidsaandeelhouders tot onder de uitkoopgrens van $5 \%$ daalt, een minderheidsaandeelhouder rekening [dient] te houden wanneer hij tot de aankoop van een minderheidspakket overgaat of een minderheidsbelang aan-

61. De nominale waarde was verhoogd tot maar liefst EUR 178.376.978 per aandeel, met het evidente doel om te voorkomen dat aandeelhouders aandelen in de verkrijger zouden moeten worden toegekend. Bovendien ontbrak een onafhankelijke fairness opinion.

62. De OK oordeelde dat de fusie in strijd was met de derde EG-richtlijn (thans: Richtlijn 2011/35/EU), de fusiebepalingen in Boek 2 BW en de redelijkheid en billijkheid van art. 2:8 BW.

63. Rb. Amsterdam (pres.) 11 juni 1999, JOR 1999/174 m.nt. Van Solinge.

64. Rb. Amsterdam 6 februari 2002, JOR 2002/61.

65. HR 14 september 2007, NJ 2007/610 m.nt. Maeijer (Versatel I).

66. Hof Amsterdam (OK) 27 september 2005, JOR 2005/272 (Versatel I), r.o. 3.15 .

67. Hof Amsterdam (OK) 27 september 2005, JOR 2005/272 (Versatel I), r.o. 3.16. 
houdt'. Deze overweging, die in belangrijke mate een citaat uit de wetsgeschiedenis betreft, ${ }^{68}$ zou ik aldus parafraseren dat de minderheidsaandeelhouder er rekening mee dient te houden dat hij in de algemene vergadering kan worden overstemd, mogelijk ook bij besluitvorming waarmee er daadwerkelijk of de facto een einde wordt gemaakt aan zijn aandeelhouderschap.

De Hoge Raad maakte echter twee voorbehouden bij deze algemene regel. Ten eerste overwoog hij dat een dergelijke gedaantewisseling onrechtmatig kan zijn jegens de minderheidsaandeelhouders als die 'daardoor onevenredig worden benadeeld'. Een begrijpelijke caveat, maar als het bestuur van de doelvennootschap eenmaal heeft vastgesteld dat het belang van de vennootschap ermee gediend is dat er een route naar honderd procent aandeelhouderschap wordt gecreëerd, zal de uitstoting van de minderheid op zichzelf mijns inziens zelden kwalificeren als een dergelijke onevenredige benadeling. ${ }^{69} \mathrm{Die}$ onevenredige benadeling zal mogelijk wel kunnen voortvloeien uit de vorm van de gekozen back-end structuur, het effect daarvan op de opbrengst voor de resterende minderheidsaandeelhouders en de communicatie daarover (zie par. 5.2 hiervoor).

Als tweede voorbehoud overwoog de Hoge Raad dat 'een besluit tot fusie dat enkel en alleen de strekking heeft minderheidsaandeelhouders uit te stoten, in strijd kan zijn met hetgeen van het bestuur van een beursvennootschap jegens haar aandeelhouders op de voet van art. 2:8 BW wordt gevorderd door de redelijkheid en billijkheid' (cursivering JB). De formulering van deze overweging in de context van een back-end structuur is mijns inziens enigszins ongelukkig. ${ }^{70}$ Doorgaans wordt deze overweging zo uitgelegd dat er ook andere zakelijke motieven aan de post-closing herstructurering ten grondslag zouden moeten liggen. In transactiedocumentatie wordt daarom vaak aan dit vereiste lippendienst bewezen door te verwijzen naar allerhande business reasons voor de herstructurering. ${ }^{71}$ Maar wat voegt dat precies toe? Mijns inziens is het doel van een backend structuur nu juist naar haar aard niets anders dan het uitstoten van de minderheid, of positiever geformuleerd: het verkrijgen van honderd procent eigendom. De in paragraaf 7.1 besproken achterliggende redenen om tot dat volledige eigendom te komen, zullen vrijwel altijd kunnen worden aangemerkt als zakelijk en redelijk. In welk geval is dan sprake van een besluit dat de Hoge Raad hier op het oog heeft? Bedoelt de Hoge Raad dat back-end structuren niet als unilaterale uitstotingsregeling mogen worden gebruikt, bijvoorbeeld bij een geschil tussen aandeelhouders, als er verder geen zakelijke redenen voor de uitstoting bestaan?

68. Zie Kamerstukken II 2005/06, 30419, 8 (NV), p. 17.

69. In gelijke zin C.J.C. de Brauw, Besluitvorming over strategie en openbare biedingen anno 2018, Ondernemingsrecht 2018/11, afl. 2, p. 56.

70. Zie daarover ook kritisch P.D. Olden, Pre-wired asset sale, WPNR 2014/7037.

71. Zie bijv. p. 55 van het Offer Memorandum van NN Group N.V. inzake haar bod op Delta Lloyd N.V.
Ik zou dan ook menen dat aan dit tweede voorbehoud niet te veel gewicht moet worden toegekend, aangezien dat er in de kern op neerkomt dat de vennootschap en de bieder een valide zakelijke reden moeten hebben om honderd procent te willen verkrijgen, en die zal er mijns inziens vrijwel altijd zijn. In dit verband zouden wij kunnen leren van de rechtspraak in Delaware. Daar werd in 1977 een vergelijkbaar criterium geformuleerd: freeze-out mergers moesten een 'legitimate business purpose' hebben, en mochten niet geschieden 'for the sole purpose of eliminating a minority'. ${ }^{72} \mathrm{Na}$ stevige kritiek in de literatuur is dit uitgangspunt in 1983 alweer verlaten, en ligt de nadruk sindsdien op fair dealing en fair price. ${ }^{73}$

Een terughoudende interpretatie lijkt mij tot slot ook wenselijk in het licht van het vrij draconische gevolg van schending van artikel 2:8 BW in deze context: de back-end besluiten zouden daarmee aantastbaar worden. Dat gaat veel verder dan bijvoorbeeld een succesvolle appraisal claim in Delaware, die de transactie in stand laat en uitsluitend leidt tot een recht op de fair value van de aandelen (zie par. 2.3).

\section{Bijzondere voorwaarden aan back-end- transacties?}

\subsection{Gekwalificeerde meerderheidsbesluiten}

Hoewel uit de wet en jurisprudentie dus lijkt te volgen dat de vennootschap en de bieder in beginsel vrijelijk van de herstructureringsmogelijkheden in Boek 2 BW gebruik kunnen maken om een pad naar honderd procent eigendom te creëren, is er in Nederland een marktpraktijk ontstaan waarin back-ends aan additionele voorwaarden moeten voldoen. Zo gold bij een klein aantal transacties dat de back-end de goedkeuring behoefde van een besluit van de algemene vergadering genomen met een grotere meerderheid dan wettelijk voorgeschreven. ${ }^{74}$ In deze lijn heeft Eumedion in 2016 voorgesteld om de wettelijk vereiste meerderheid bij goedkeuring van een activa/ passiva-transactie te verhogen naar twee derde van de uitgebrachte stemmen als minder dan de helft van het geplaatst kapitaal vertegenwoordigd is, waardoor deze dus gelijk zou worden gesteld met de benodigde meerderheid voor een juridische fusie. ${ }^{75}$

\subsection{Aanmeldingsdrempels}

Terwijl gekwalificeerde meerderheidsvereisten slechts sporadisch voorkomen, is het gebruik van aanmeldingsdrempels inmiddels standaard geworden in de historisch gegroeide backend-praktijk. De implementatie van de pre-wired back-end wordt vrijwel altijd voorwaardelijk gemaakt aan het succes van

72. Singer v. Magnavox Co., 380 A.2d 969 (Del. 1977). Zie hierover uitgebreid T. Vos, Freeze-outs of minority shareholders: A comparative law and economics approach (master thesis Leuven), 2016.

73. Weinberger v. UOP, Inc., 457 A.2d 701 (Del. 1983).

74. Bijv. bij de back-end grensoverschrijdende juridische fusies bij Klépierre/ Corio in 2014 en Sweco/Grontmij in 2015.

75. Eumedion Position Paper, Positie minderheidsaandeelhouders in ondernemingen met een controlerend aandeelhouder, d.d. 28 juni 2016 (hierna: Eumedion 2016), p. 16. 


\section{Maandblad \\ Ondernemingsrecht}

het daaraan voorafgaande bod: de back-end mag uitsluitend worden geëffectueerd als de bieder na gestanddoening een bepaald minimumpercentage van de aandelen in de doelvennootschap houdt. Partijen durven dus niet te vertrouwen op louter de goedkeuring van de back-end door de algemene vergadering conform de voorschriften van Boek $2 \mathrm{BW}$, maar introduceren eigenhandig en onverplicht een additionele drempel. Die drempel ziet niet op de stemming tijdens de BAVA, maar op het aantal onder het bod aangeboden aandelen. In zekere zin wordt daarmee dus het probleem dat men met de back-end structuur probeert te verhelpen via de achterdeur weer binnengelaten.

In veruit de meeste pre-wired transacties is daarbij een aanmeldingsdrempel gehanteerd van $80 \%$ van het geplaatst kapitaal. ${ }^{76}$ Volgens Eumedion zou deze '80\%-voorwaarde' zelfs moeten worden verankerd in de Corporate Governance Code of de wet als zij geen marktpraktijk zou blijven. ${ }^{77}$ Over de ratio van dit percentage bestaat echter geen duidelijkheid. In de praktijk wordt regelmatig aangevoerd dat men daarmee veiligstelt dat de transactie kan rekenen op de steun van de 'meerderheid van de minderheid'. ${ }^{78}$ Dat argument klinkt wellicht lekker, maar snijdt geen hout. Een drempel van $80 \%$ garandeert dat meer dan driekwart de transactie steunt, maar dat heeft op zichzelf nog niets te maken met een meerderheid van een minderheid. Het concept 'meerderheid van de minderheid' is alleen zinvol en toepasbaar als voorafgaande aan het peilmoment duidelijk is wie de (geconflicteerde) meerderheid is en wie de (nietgeconflicteerde) minderheid vormt. Die situatie doet zich bijvoorbeeld voor als de bieder reeds voorafgaande aan het bod een controlerende positie heeft in de doelvennootschap. In dat geval kan de invloed van de bieder worden geneutraliseerd door op te nemen dat meer dan $50 \%$ van de overige aandeelhouders hun aandelen moet hebben aangeboden. ${ }^{79}$

Een concrete rechtvaardiging voor het gangbare percentage van $80 \%$ ontbreekt kortom en bij een aantal recente transacties hebben partijen de drempel ook lager gelegd. Zo gold voor de back-end-fusie in de NN Group/Delta Lloyd-transactie een aanmeldingsdrempel van slechts $67 \%$. En in het bod dat Intel Corporation in 2017 deed op Mobileye N.V. was de back-enddrempel ook op $67 \%$ gezet, maar door de toekenning van een 15\%-call option kon de back-end de facto worden geïmplemen-

76. Strikt genomen is de term 'aanmeldingsdrempel' niet helemaal juist, omdat de drempel altijd wordt gebaseerd op het totaal van (1) de onder het bod aangemelde aandelen en (2) de door de bieder reeds gehouden aandelen.

77. Eumedion 2016, p. 14.

78. Zie bijv. De Brauw 2017, p. 752.

79. Vgl. het recente bod van het consortium van PAI en Jobson op Koninklijke Wessanen N.V. Aangezien Jobson reeds 25,74\% van de aandelen houdt, is gekozen voor een aanmeldingsdrempel die het consortium eenzijdig mag verlagen naar $76 \%$, wat impliceert dat meer dan $67,6 \%$ van de overige (niet-geconflicteerde) aandeelhouders dient aan te melden. teerd als slechts $52 \%$ van het uitstaande kapitaal op het bod was ingegaan..$^{80}$

\subsection{CB\&I/McDermott: een activa/passiva-transactie zonder aanmeldingsdrempel}

In het licht van voorgaande ontwikkeling is de overname in 2018 van het in New York genoteerde Chicago Bridge \& Iron Company N.V. (hierna: CB\&I) door het Panamese McDermott, Inc. mijns inziens interessant. ${ }^{81}$ Die overname was gestructureerd als een verkoop van activa en passiva door CB\&I aan McDermott, vergelijkbaar met de in paragraaf 3 vermelde transacties. ${ }^{82}$ Zoals gebruikelijk was die activa/passiva-transactie uitsluitend voorwaardelijk aan de wettelijk vereiste aandeelhoudersgoedkeuring. Wat de transactie echter bijzonder maakt, is dat voorafgaande aan de implementatie van de activa/passiva-transactie een ruilbod plaatsvond van McDermott op CB\&I, met het doel om de aandeelhouders van CB\&I een (fiscaal gunstige) early exit opportunity te bieden. De gestanddoening van dit bod was evenmin voorwaardelijk aan enige aanmeldingsdrempel. De transactie zou kortom doorgang vinden ongeacht of er ook maar één aandeel zou worden aangeboden, mits tijdens de BAVA voorafgaande aan het bod de vereiste aandeelhoudersgoedkeuring werd verkregen. In de transactiedocumentatie werd de activa/passivatransactie nadrukkelijk gepresenteerd als de core transaction en het bod slechts als een flankerende uitstapmogelijkheid waarvan aandeelhouders al dan niet gebruik konden maken. ${ }^{83}$ Ofwel: het ging hier niet om een openbaar bod gevolgd door een activa/passiva-transactie, maar om een activa/passivatransactie voorafgegaan door een openbaar bod. Binnen dit perspectief waren de klassieke back-end en front-end dus van plaats gewisseld. Hoewel de gehele transactie juridisch-technisch uit precies dezelfde stappen bestond als een 'regulier' openbaar bod met een activa/passiva-back-end, zagen partijen door de activa/passiva-transactie centraal te stellen geen aanleiding om die transactie voorwaardelijk te maken aan het succes van het voorafgaande bod. Bij de keuze voor deze transactiestructuur speelde mee dat CB\&I in financieel zwaar weer verkeerde en deal certainty voor partijen daarom van cruciaal

80. Zie de Schedule 14D-9 van Mobileye van 5 april 2015, p. 2. Zie ik het goed, dan stond de purchase agreement van 12 maart 2017 het toe dat Intel de call option zou uitoefenen en vervolgens de activa/passiva-transactie zou implementeren, waarbij de onder de call option verkregen $15 \%$ zou kunnen worden meegeteld bij het behalen van de 67\%-grens. Overigens hield Intel na gestanddoening van haar bod $97,3 \%$ van de aandelen, zodat zij zich met behulp van de wettelijke uitkoopprocedure van de resterende minderheid kon ontdoen.

81. Zie het persbericht van partijen van 18 december 2017. In het kader van full disclosure zij vermeld dat ik bij deze transactie betrokken was.

82. Direct voorafgaande aan die activa/passiva-transactie vond binnen het CB\&I-concern een juridische driehoeksfusie plaats om een 'schone' holding te creëren, zoals beschreven in par. 5.1.

83. Zo werd in het proxy statement/prospectus van 24 januari 2018 opgetekend: 'Pursuant to the terms of the Business Combination Agreement, McDermott and CB\&I have agreed to combine their businesses by a series of transactions (...) that we refer to as the "Core Transactions", preceded by McDermott (...) making an Exchange Offer (together with the Core Transactions, the "Combination") for shares of CB\&I Common Stock.' 
belang was. $\mathrm{Na}$ de gestanddoening van het bod hield McDermott $65 \%$ van de aandelen in CB\&I. Daarom ontving de overige $35 \%$ de koopprijs door middel van de activa/passivatransactie en vereffeningsuitkering. ${ }^{84}$

\subsection{Rechtvaardiging bijzondere voorwaarden aan pre- wired back-end?}

De CB\&I/McDermott-transactie illustreert mijns inziens een fundamentele vraag: waarom zouden activa/passiva-transacties en juridische fusies aan bijzondere voorwaarden moeten voldoen, zoals aanmeldingsdrempels of gekwalificeerde meerderheidsbesluiten, als die direct na een openbaar bod plaatsvinden? Wat rechtvaardigt dit verschil met de stand-alone acti$\mathrm{va} /$ passiva-transacties en juridische fusies zoals vermeld in paragraaf 3, die 'slechts' voorwaardelijk waren aan de wettelijk voorgeschreven aandeelhoudersgoedkeuring? 85

Een bijzonder element aan de 'reguliere' (niet-pre-wired) herstructurering na een openbaar bod is vanzelfsprekend dat de bieder na gestanddoening controle heeft over de besluitvorming in de algemene vergadering van de doelvennootschap, en dat brengt het risico mee dat er bij de besluitvorming over de back-end transacties onvoldoende rekening wordt gehouden met de belangen van de resterende minderheidsaandeelhouders. Er zijn verschillende manieren waarop dit risico kan worden gemitigeerd. Zo kunnen in Delaware grootaandeelhouders die een transactie met de vennootschap verrichten de bescherming van de business judgement rule activeren door de transactie voorwaardelijk te maken aan instemming van een Special Committee, bestaande uit de onafhankelijke directors, en van een meerderheid van de onafhankelijke minderheids-

84. Wat de CB\&I/McDermott-transactie tevens bijzonder maakt, is dat het Panamese McDermott uitsluitend betaalde met aandelen in haar eigen kapitaal, zowel voor de gekochte activa en passiva als voor de aandelen aangeboden onder het bod. Anders gezegd, de aandelen van de minderheidsaandeelhouders die niet op het ruilbod waren ingegaan, werden door de implementatie van de activa/passiva-transactie de facto omgezet in aandelen in de (beursgenoteerde) Panamese bieder. Materieel gezien komt dit samenstel van transacties dus erg dicht in de buurt van een grensoverschrijdende (outbound) fusie van een Nederlandse vennootschap met een Panamese vennootschap. Dit illustreert maar weer eens dat bij gebrek aan een wettelijke faciliteit de praktijk op zoek gaat naar alternatieven. Overigens was zowel CB\&I als McDermott genoteerd aan de New York Stock Exchange en hielden beide bedrijven hun hoofdkantoor in de VS, zodat deze 'verhuizing van Nederland naar Panama' niet moet worden overschat.

85. Zelfs de activa/passiva-transactie tussen Super de Boer en Jumbo in 2009 was slechts afhankelijk van een aandeelhoudersbesluit genomen met een volstrekte meerderheid van de uitgebrachte stemmen, terwijl grootaandeelhouder Casino met haar belang van $57 \%$ in Super de Boer de totstandkoming van de 2:107a-goedkeuring kon bewerkstelligen zonder de instemming van enige andere aandeelhouder. Een nog verregaander voorbeeld betreft de overname van alle activa en passiva van Equant N.V door France Telecom in 2005, waarbij koper France Telecom als houder van $54,1 \%$ van de aandelen in Equant de aandeelhoudersgoedkeuring erdoorheen kon stemmen. aandeelhouders. ${ }^{86}$ In Nederland is het sinds de tweede Versatel-beschikking van de Hoge Raad praktijk dat dergelijke transacties goedkeuring behoeven van de onafhankelijke commissarissen of niet-uitvoerende bestuurders van de doelwitvennootschap. ${ }^{87}$

Maar het voorgaande risico op belangenverstrengeling speelt in de regel niet bij de pre-wired back-end structuur. Het aardige van de pre-wired back-end is nu juist dat die wordt goedgekeurd voorafgaande aan de gestanddoening van het bod; op een moment dus dat de bieder (doorgaans) nog geen controlerende positie in de algemene vergadering inneemt. De wettelijk vereiste aandeelhoudersgoedkeuring komt dus tot stand in een niet-geconflicteerde algemene vergadering en zou daarom in beginsel een voldoende mandaat moeten bieden voor de implementatie van de back-end transacties.

De gangbare praktijk om de back-end voorwaardelijk te maken aan een aanmeldingsdrempel vloeit kortom niet voort uit zorgen over geconflicteerde besluitvorming, maar vindt naar mijn idee zijn oorsprong in een algemeen ongemak dat men voelt bij de eenzijdige beëindiging van het aandeelhouderschap van de resterende minderheid en de wens om eventuele daarmee samenhangende 'litigation risks' te mitigeren. Dit ongemak klinkt ook door in het handboek over beursovernames, waarin De Brauw noteert dat de keuze voor een stand-alone activa/ passiva-transactie of juridische fusie boven de 'koninklijke' en 'normale' route van het openbaar bod een bijzondere rechtvaardiging behoeft. ${ }^{88}$ Dit lijkt mij een juiste weergave van hoe dit in de praktijk door velen wordt gevoeld, maar het is de vraag of dit volgt uit de hierboven besproken wet en jurisprudentie. Ik lees daarin geen principieel uitgangspunt dat de overname van een Nederlandse beursvennootschap in beginsel dient plaats te vinden door een openbaar bod waarop iedere individuele aandeelhouder kan besluiten al dan niet in te gaan, noch dat een dergelijke overname de instemming behoeft van ten minste $80 \%$ van het kapitaal.

\section{Conclusie}

Zolang de Europese fusieregels in de weg blijven staan aan een op Amerikaanse leest geschoeide driehoeksfusie, zullen prewired back-end structuren in Nederland een belangrijke functie blijven vervullen bij overnames van beursvennootschappen.

86. In re MFW Shareholders Litigation, 67 A.3d 496 (Del. Ch. May 29, 2013). De Brauw heeft (mijns inziens terecht) betoogd dat bestuurders en commissarissen van Nederlandse doelwitvennootschappen terughoudend zouden moeten zijn bij de vrijwillige introductie van meerderheidvan-de-minderheid-vereisten (De Brauw 2017, par. 5.1.9.12).

87. HR 14 september 2007, JOR 2007/239 m.nt. Bartman (Versatel II). Zie bijv. de overname van EVC International N.V., waar grootaandeelhouder Ineos (na een tweede bod) de activa/passiva-transactie en liquidatie er zelfstandig doorheen kon stemmen. Die transactie was onderworpen aan goedkeuring door een onafhankelijke commissaris en de minderheid mocht de gebruikte fairness opinion laten toetsen door een onafhankelijke deskundige. Dat bood in de ogen van de OK voldoende bescherming tegen de belangenverstrengeling. Zie Hof Amsterdam (OK) 21 december 2005, JOR 2006/8, waarover Olden 2014.

88. De Brauw 2017, p. 883, 890, 892 en 911. 


\section{Maandblad}

Ondernemingsrecht

Die structuren hebben zich de afgelopen jaren ontwikkeld tot een effectief instrumentarium om na een openbaar bod een route te creëren naar honderd procent controle. Daarbij valt wel op dat de back-end transacties in de praktijk aan additionele voorwaarden worden onderworpen, zoals aan het bod gekoppelde aanmeldingsdrempels. Terwijl in Angelsaksische jurisdicties, zoals Delaware, algemeen wordt aanvaard dat een bieder honderd procent eigendom moet kunnen afdwingen als de transactie kan rekenen op de steun van meer dan 50\% van het kapitaal, lijkt men in Nederland moeite te hebben met de gedwongen beëindiging van het aandeelhouderschap van de minderheid die de transactie niet heeft gesteund. Het is echter de vraag of dat terecht is als het belang van de vennootschap vergt dat er een route naar honderd procent wordt gecreëerd en de transactie is goedgekeurd door een niet-geconflicteerde algemene vergadering conform de vereisten van Boek $2 \mathrm{BW}$. 